\title{
Bridging the Industry- Academia skill gap A conceptual investigation with special emphasis on the management education in India
}

\author{
PrachiKapil \\ Assistant Professor, Department of Management Studies,Maharishi Markandeshwar University, Solan (H.P.)
}

\begin{abstract}
India is a growing economy and has the attention of world players for investment and expansions. Due to this arises a need for ready-for-the-job people.But contrary to this, there is a large set of employees who need to be skilled, re-skilled and up-skilled to meet the needs of the changing environment. This is only possible through the active role of industry in sharing the know-how and expertise and academia in developing programmes and solutions to fill the void. India has stock of some 22 million graduates, including 6 million science graduates, 1.2 million with engineering degrees and 600,000 doctors, according to the data compiled by The Economic Times Intelligence Group, the NASSCOM and other industry sources. With this present scenario in mind, this paper is an effort to highlight a number of current and future initiatives aimed at gearing up and accelerating interdependence between academic and industrial prospects in India by laying special emphasis on research and development initiatives, governance of Indian management schools, building centres of excellence and attractive packages to allure competent faculty.
\end{abstract}

\section{Introduction}

Necessity is the mother of invention. So is Academia-Industry collaboration, dictated by necessity. Over the last decade and a half, world has become a global village .Employers today, operate in an environment that demands new and constantly developing skills to retain global competitiveness. Although India's higher education system contributes about 350,000 engineers and 2.5 million university graduates annually to our workforce, yet at any point of time, about 5 million graduates remain unemployed. A survey done by McKinsey Global Institute shows multinationals find only 25 percent of Indian engineers employable, and a NASSCOM report highlights shortage of 500,000 knowledge workers by 2015 .

In response, the government has been taking initiatives by investing in education and training by allotting a sound proportion of national income towards these sectors. However, the effort has been inadequate to address the direct needs of the corporate sector. The India Labour Report 2009 in its finding said,by 2026, 1.4 billion youth will enter the labour force. The reality, however, is different. At present, about $53 \%$ of employed youth suffer from some degree of skill deprivation which makes them unemployable.

\section{Need To Bridge the Gap}

The reason that there are few jobs to be found in academics is not because there are too few colleges, universities, departments, or programs. Rather, there are too many. The problem is that the bulk which apply for these jobs are far too huge .Now- a- days there are simply too many PhDs produced every year for the higher education establishment to absorb them all, but the quality has certainly deteriorated. Today, businesses are looking for innovative solutions from the academia to help meet their business needs of higher productivity and lower costs, yet increase efficiencies. As far as talent in India is concerned, attention needs to be paid towards technical and management resources as these are crucial to knowledge-based industries. A market-driven approach to higher education has to be fostered in order to encourage manpower development from the grass root level itself.

Reasons behind the Gap between Academia and Industry

1) Academicians and industrialists have a different mindset; therefore both have different perspectives and expectations.

2) The curriculum is static in nature while its application is dynamic.

3) Both academicians and industrialists are pursing different goals entirely. The academic is striving for recognition from his or her peers. The Industrialist is striving to survive.

4) Lukewarm attitude of lecturers to surrender themselves for trainings and workshops.

5) Industry thinks in terms of short range goals whereas academic has a long range perspective.

6) Industry prefers proven solutions with a low risk, whereas academia is interested in creating new solutions with a high innovation rate.

7) Industry seeks the minimum solution to minimize their risk, whereas academia strives for a maximum solution to maximize their recognition. 


\section{Management Education in India}

India and many of the other developing countries face a deficit of available human intellectualcapital necessary to manage and sustain their rapidly transforming economic enterprises andcapital markets. FDIs from across the globe are gushing towards India. Our country today boasts of having more than $950 \mathrm{~B}$ - schools of various kinds, including the elite Indian Institutes of Management (IIMs), universities with business departments, and autonomous private business institutes with student strength of 72,000. To fill up the gap in demand for management education, hundreds of management schools sprang up through the 1990s. The IIMs are still regarded as the temples of learning while some other ivy league schools, which have come up during the last 30 years have firmly established themselves as institutes of repute.

\section{b. Clarity about the expectation of the employer: Skills needed}

Every student fantasises of a lucrative job once MBA is over. But little do they know that this flowery picture is followed by a plethora of rejections at the placement sessions. This happens because of the communication gap between the employer and the prospective employee. The employer now-a-days looks for competencies such as problem solving, decision making, multi tasking and the like. Students should be accustomed to work in the industry oriented environment during their academic tenure so that the skills and competencies come naturally to them.

\section{a. Generation of Knowledge rather than distributing knowledge}

Industry - Institute interface is a critical dimension for any management institute as thisinterface decides the extent to which the institute becomes an acceptable brand.

Industry can gain from the expertise and knowledge cultivated by the management institutes and the management institutes can take advantage from the field experience and the industry exposure through projects, guest lectures and seminars.

\section{c. Recognition of employability skills imparted through the Indian Higher Education System:}

- Lack of Industry orientation - the process of evaluation is still examination based rather than project based.

- Rigidity - Since all educational institutions are under the ambit of UGC regulations the process of reevaluation of course content becomes non-flexible.

- Lack of industry experience of the teachers.

- Lack of attention towards pure sciences and research.

\section{c. Skills Imparted through the regular MBA programs}

To emphasize skill - building and real time learning, Indian B - schools have adopted the western business education model which includes case studies. Though B-schools have tried to implement this approach but it has, some way or the other, failed to achieve its purpose due to deficiency of Indian cases. The curriculum of regular MBA programmes today stresses on communication skills, bothwritten and verbal, which establishes desirable and qualified student profiles that encourages readyacceptance of students in a wide range of workplaces. Keeping in mind the current scenario of rising Indian economy in the latest years, B - schools should encourage students and academicians to use newly developed technology to create innovative domestic and international services, further giving impetus to strong entrepreneurial and dynamic leadership to face the upcoming challenges with utmost audacity and competency.

\section{Perspective Analysis of Emerging Sectors}

1. Drugs \& Pharmaceutical: Globally, the drug sector had grown at a rate of $7 \%$ while India's drug sector grew by $10 \%$. Pharmacy Education in India needs to take cognizance of the deficiencies and modify their curriculum, to adapt to the needs of modern pharmaceuticals. The government, academia and the industry have made efforts to restructure the course content but still a vast population of this segment lacks experience which is a vital necessity for the concerned sector.

2. Biotechnology: The biotechnology sector in India is witnessing accelerated growth and is rapidly attaining critical acclaim in terms of skills and capabilities to become a truly global player. The industry is growing at a rate of 37.5 percent annually. With the growth of biotechnology sector, not only has the number of opportunities gone up drastically but also the pay packets that a bio-science student commands. With a large number of biological sets to go off patent, the biogenetics' sector seems poised to take the big leap.. The Bio- Informatics sector in collaboration with IT and ITES is set to take a big leap but fewer post doctorates as compared to other countries and less acclimatization to industrial research acts as an obstacle and hinders the growth of budding talent in this sector.

3. IT/ITES: India has become a much sought after destination for IT/ITES outsourcing firms because it has outshined its competitive economies in the following areas: 
- A large base of English-speaking graduates;

- Technically-qualified IT professionals;

- Competitive billing; and

- High productivity.

The headcount is steadily expected to grow at the rate of 30 percent per year in the time to come. Besides, IT/BPO makes up around 13.5 percent of the export revenues of the country.

\section{Youth unemployment statistics}

- In the period November 2012-January 2013, 993,000 young people aged 16-24 were unemployed, up 48,000 on the previous quarter but down 45,000 on the previous year.

- The unemployment rate for those aged 16-24 was $21.2 \%$, up 0.9 percentage points compared with the previous quarter but down 1.1 percentage points compared with the previous year.

- 1.62 million 18-24 year olds were economically inactive in November 2012-January 2013, 62,000 fewer than in the previous quarter and 96,000 fewer than in the same period in the previous year.

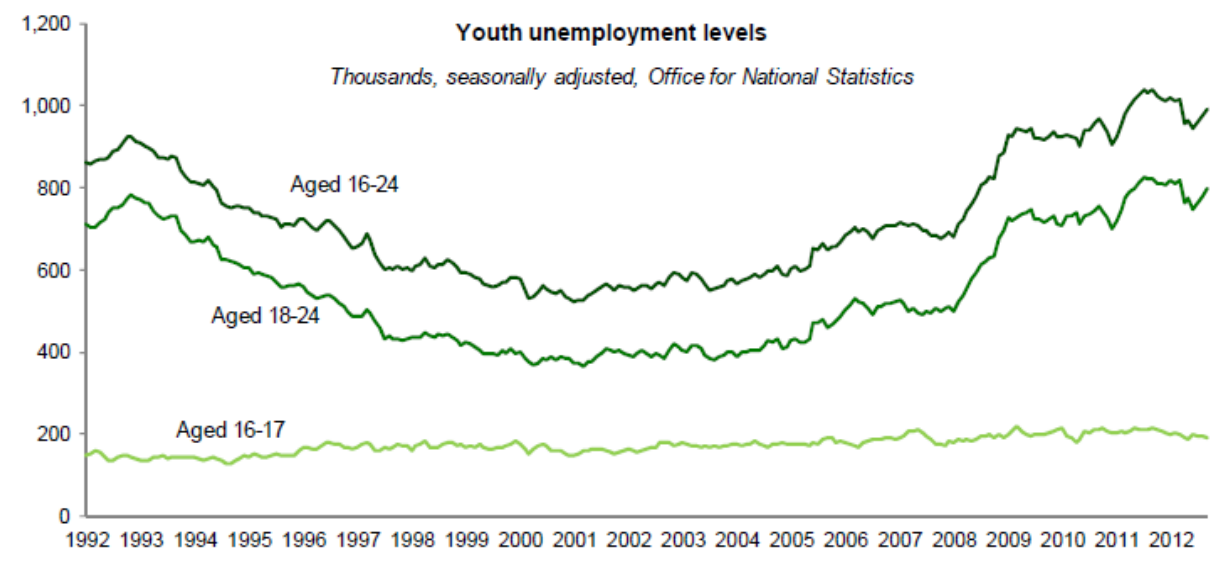

The unemployment rate for $18-24$ year olds is $19.2 \%$, while for $16-17$ year olds the rate is $37.3 \%$. The unemployment rate for 16-17 year olds has increased since the early 2000s even though the total number unemployed has remained relatively steady. This may be explained by the increasing numbers remaining in full time education and thus remaining economically inactive.

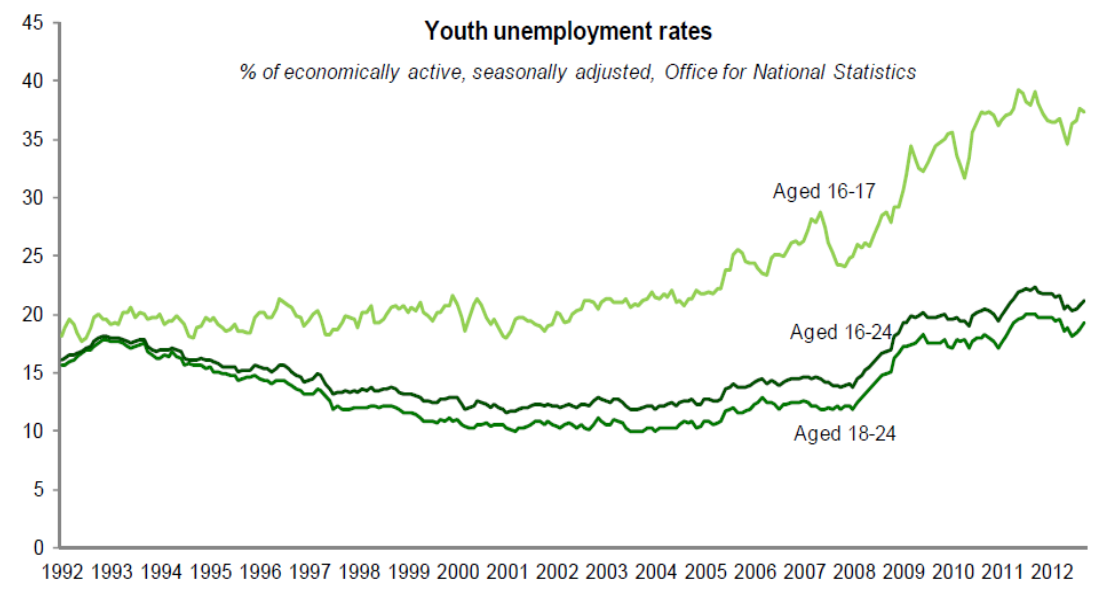

The youth unemployment statistics include people in full-time education. If people in full-time education are excluded, there were 672,000 unemployed 16-24 year olds in November 2012-January 2013, up 46,000 compared with the previous quarter but down 55,000 compared with the previous year. The unemployment rate for 16-24 year olds not in full-time education was 19.0\% in November 2012-January 2013, up 1.1 percentage points on the previous quarter but down 1.7 percentage points on the previous year. 


\section{Jobseekers allowance claimants}

The claimant count for those aged 18-24 was 415,000 in February 2013, down 2,600 on January and down 65,200 on February 2012 (note: computerised claims only; 16 and 17 year olds can only claim JSA in exceptional cases).

18-24 year olds claiming Jobseekers Allowance

thousands, computerised claims, seasonally adjusted, ONS

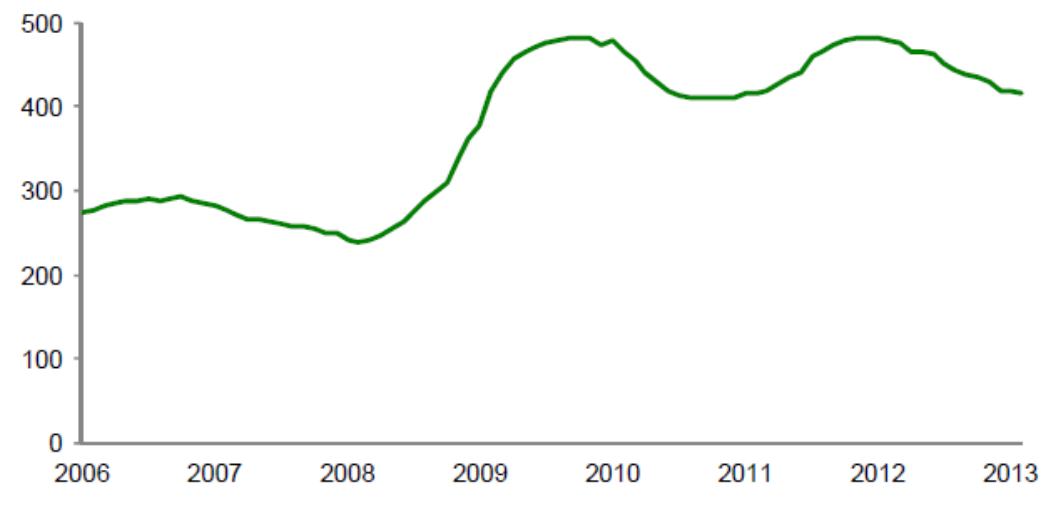

\section{Industry Viewpoint:}

1. Improvement Areas in Management Education

- It is felt that Dual specialization should be allowed for marketing and finance as both are interdependent and decisions pertaining to one has implications on the other.

- Emphasis should be laid on the foundation of a subject. Students needed to develop values like passion, commitment, and integrity and they should be a fundamental part of the curriculum.

- Impetus should be on the personal and holistic development of students through membership of associations and attending national seminars. Every student has a different academic background, knowledge environment and work experience and hence the learning styles vary accordingly.

- Bridging the gap between theory and practical through better industry interface: The need of the hour is that students need to imbibe the skills to think like leaders. This could only happen if there is awareness of industry environment and if they were application - oriented.

\section{Curriculum and syllabus up gradation:}

- Curriculum finalization

The curriculum should be finalised in consultation with industry experts and necessary changes should be made whenever required. Value adding courses, role - plays and relevant case studies should be an indispensable part of the curriculum. Live research should be brought to the academic institutions to make understanding and applicability better. Mr. Ajay Piramal, the Chairman of Nicholas Piramal (NPIL) was a regular visitor to B Schools to share his experiences. It was their belief that such practices enhance productivity.

- Human Capital management

HR is a core specialisation in all B-schools. Inspite of the various industry specific modules being introduced in this field, it has failed to fulfil the industrial requirements. HR managers believe that management trainees should have the practical know how of laws, labour legislations, competency mapping and compensation management. Words like motivation, leadership and team building should not be restricted to books rather they must be deeply rooted in their personality.

\section{Faculty}

Faculty is considered as fountainhead of knowledge and every student looks forward to his/her teachers for answers to their curiosity. Industrial giants like P\&G, Philips and Barista feels that degrees/doctorates do not matter. What matters is the experience the faculty has in terms of consulting, research work and connecting with the students. The question to ponder on is whether teaching is just a job or actually it is a source of contentment after delivering your best. 


Issues Forward Path
\begin{tabular}{|l|c|c|}
\hline Issues have & Forward Path \\
\hline $\begin{array}{l}\text { Faculty } \\
\text { theoretical/academic } \\
\text { orientation }\end{array}$ & $\begin{array}{l}\text { Introduce compulsory consultancy } \\
\text { Break their teaching periodically for interaction with industry } \\
\text { Build a 'research attitude' in the institute }\end{array}$ \\
\hline $\begin{array}{l}\text { Selection of faculty should } \\
\text { not be based on } \\
\text { degrees/doctorates }\end{array}$ & - $\begin{array}{l}\text { Select on basis of their ability to transmit new learning, quality of industry } \\
\text { exposure, passion for teaching and students }\end{array}$ \\
\hline $\begin{array}{l}\text { Core faculty has the } \\
\text { deepest influence on } \\
\text { students }\end{array}$ & - $\begin{array}{l}\text { Ratio of core to visiting/ industry faculty should be at least 50:50. } \\
\text { Enforce the use of live case studies as done at Harvard Business School } \\
\text { Case studies used should be filtered, marked for learning outcomes and teaching } \\
\text { notes. There should be some standardization on level/quality/ relevance used at the } \\
\text { start of each semester. }\end{array}$ \\
\hline
\end{tabular}

Source: www.ficci-hen.com

\section{Research \& Development}

Research is a collaborative effort of various sectors and so the consequences are also collective. It contributes in the personal growth of the faculty, respective students and also for the society at large.

$R \& D$ is a wheel with many spokes spreading in all directions. For faculty, it will be personal growth, for students it will amount to innovative learning experience and fresh, creative ideas for the industry."

\section{Feeling of denunciation while working for the government sector}

There is a delusion in the minds of the Indian student as well as the society that rejected students work for the government sector. This misconception can be removed only if the gap between the academia, industry and government is bridged by producing quality managers and the best work is done in the government sector. A proper link needs to be established between industries (which will sponsor), institutes (which will provide platform to study) and governments (which will get the feedback).

\section{Challenges}

In today's era of neck to neck competition, a blend of knowledge, skills and abilities is a prerequisite to survive in the market. Given the current high-paced growth and dynamic investment climate in India, the demand for knowledge workers with high levels of technical and soft skills will only increase. Over the past fifteen years, India has produced 1.6 million professionals and faces the uphill task of producing another 0.8 million in the next two years .In this demand-supply gap scenario, it has become complicated to create a group of voracious and industry oriented human resource. According to the All India Council of Technical Education, the number of technical schools in India, including engineering colleges, has increased three fold in the last decade. According to official statistics, not more than 7 per cent of Indians in the age group 18-25 go to college. Leaving aside higher education, the scenario of elementary education in India is very disheartening as nearly 40 per cent of people over the age of 15 are illiterate. The best and most selective universities generate too few graduates, and new private colleges are producing graduates of uneven quality. To further aggravate the problem, the syllabi and curricula of universities and educational institutions is obsolete, irrelevant and a total misfit in the everyday changing technological and competitive environment. . Therefore the freshers are not accustomed to working in the practical industrial environment and companies have to shun out extra money and time to orient and train them. Since the industries have to compete at the global level, there criteria for selection of industry conversant people has also intensified. The new brigade of students should be competent in transformational leadership, business ethics and values, group dynamics and team building to make a faction of highly informed, industry acquainted knowledge workers.

\section{Recommendations}

\section{a. Improve accreditation and governance rules in academic institutions}

A professional body including representatives from the industry, academia and government needs to be established to grant recognition to institutes and also to cross verify that the basic standards pertaining to infrastructure, adequately equipped libraries and qualified and experienced teaching staff are fulfilled.

\section{b. Build Centres of Excellence and Expertise}

- Training must be quality and expertise oriented specially for scientific and professional students. pool

- Promote Research Translation centres in India to facilitate conversion of academic knowledge to industrial products.

- Upgrade the existing Research centres to become Centres of Excellence/Innovation hubs.

- Ally with leading foreign institutes to strengthen the Indian capabilities to transfer the new research \& development work to the market. 


\section{c. Effective Industry Involvement}

- Make sure that industry participates in discussions related to formulating policies wherein academia and industry can flourish as a combined entity.

- Hold business plan competitions jointly sponsored by industry and academia

- Renewal of research grants should be made to the academic institutions contingent on industry linkages.

- Help academic researchers commercialize their research findings by encouraging

academic institutions to interact with an industrial partner to promote their products.

\section{d. Attract State-of-the art teaching faculty}

- Attract high-performing Indian scientists/technocrats back to India

- Allow faculty to earn royalty on patents

- Provide extra allowances and incentives to faculty and researchers so that they feel at par with the corporate sector and psychologically feel motivated to work.

- Allow scientists to hold part-time positions in the private sector in order to have the right

blend of theory and practice.

\section{Conclusion}

Companies have adopted various new methods and strategies to acquire best and unsurpassed human resource to survive and succeed commercially in the highly competitive market. These strategies range from identification of skills, shortfalls which may occur, efforts to impart required skills, and adapt existing skills by orienting to new demands. Since the gap between academia and industry is widening day by day, the government, academic institutions and industry must come forward with some innovative and research based ideas to bridge the gap. However, we can't deny that only a holistic development of all the sectors of a country will help to outshine its competitors and succeed in its endeavour to become an empowered economy at the global platform.

Efforts should be made in line with bringing institutions of higher learning and industry together to ensure that quality is delivered bothways. A regulatory body,exclusively for management schools, must be created to regulate, monitor and ensure Q\&A (Quality \& Assurance) in delivery of education. B - Schools need to comprehend that change is the only constant and so is the demand for the day. Academia-Industry linkage requires strengthening, with an impetus on grooming the students to become effective managers and leaders of tomorrow.

\section{References:}

[1] AtreSandeep, Jain Sangeeta, \&Sharma Vivek, Impact of Communication Skills on ProfessionalEffectiveness at the Top Level of Hierarchy, Global Journal of Management and Business Studies.ISSN 2248-9878 Vol 3, Number 7 (2013), pp. 751-756.

[2] Chithra. R, Employability Skills - A Study on the Perception of the Engineering Students and their Prospective Employers, Global Journal of Management and Business Studies, ISSN 2248-9878, Vol. 3, Number 5 (2013), pp. 525-534.

[3] Jackson Dennis, Journal of Management Education 8(3) 29, An international profile of industry-relevant competencies and skill gaps in modern graduates,International Journal of Management Education, Oct 2009.

[4] King Ceridwyn, Funk Daniel C \& Wilkins Hugh, Bridging the gap: An examination of the relative alignment of hospitality research and industry priorities, International journal of Hospitality Management, Vol.30, Issue 1, March 2011, pages 157-166.

[5] Krishna Kishore, \&MajumdarMousumi,Management Education and CorporateExpectations: A Gap Analysis,Handbook of Management and Behavioural Science, Vol-7.

[6] Kumar Varun, The changing nature of organizations-A view of leadership, Global Journal of Management \& Business Studies, Vol 3, No.8,(2013), pp.905-910.

[7] NureniAyofeAzeez, \&RaheemAjetolaAzeez, Exploration of the Gap between Computer ScienceCurriculum and Industrial I.T Skills Requirements. (IJCSIS) International Journal of Computer Science and Information Security, Vol. 4, No. 1 \& 2, 2009.

[8] Raybould Mike, Wilkins Hugh,Over qualified and under experienced: Turning graduates into hospitality managers, Internationla Journal of Contemporary Hospitality Management,Vol 17, pp.203-216

[9] Solkhe Ajay, HRD Climate and Job Satisfaction- An Empirical Investigation International Journal of Computing and Business Research, ISSN (Online): 2229-6166, Vol 2, Issue 2 May 2011.

[10] Starkey Ken, Madan Paula, Bridging the relevance gap: Aligning stakeholders in the future of Management Research, British Journal of Managemnt, Vol. 12, Issue supplement 12, Dec 2001, pages S3-S26.

[11] Tranth Eileen M. , Farwell Doughlas W. \& Lee Dennis, The IS expectation gap: Industry expectations v/s academic preparation, Journla MIS, Quarterly vol. 176, Issue 3, Sep 1993, Pages 293-307.

[12] http://www.icra2012.org/files/ICRA12 IndForum Digest.pdf

[13] http://www.ficci-hen.com/Knowledge_Paper_Industry_Academia_Convergence_Bridging_t\%85.pdf

[14] http://thegradstudentway.com/blog/?p=251

[15] http://www.chennaichemistryconference.in/lectures/12-02-2011/Session\%2011/EL1.pdf

[16] http://www.slideshare.net/insighthr/bridging-the-gap-between-industry-and-academia

[17] http://www.atrion.net/innovation/published/Documents/bridging-the-it-skills-gap-giselle-lafrance.pdf

[18] http://www.reengineer.org/stevens/Harry-Sneed-CSMR2009-Stevens-Lecture-A4.pdf

[19] file:///C:/Documents\%20and\%20Settings/Administrator/Desktop/Nine\%20ideas\%20to\%20bridge\%20industry academia\%20gap\%20\%20\%20General\%20\%20\%20Times\%20Higher\%20Education.htm

[20] http://www.nsdcindia.org/pdf/it-ites-industry.pdf 